\title{
GAZDASÁGI ÉS POLITIKAI ELEMEK A II. ORBÁN-KORMÁNY GAZDASÁGPOLITIKÁJÁBAN
}

\author{
Dr. univ. Gösi János \\ föiskolai docens, Szegedi Tudományegyetem Mérnöki Kar, Szeged
}

\begin{abstract}
SUMMARY
The economical and political elements of the economic policy of II. Orbán-government Taxes crisis: banking, commerce, etc.. The flat-rate personal income tax Compulsory membership of private pension funds nationalization of assets

The retail price for repayment of residential foreign currency loans recorded a large loss for the banks II. Orbán government's economic policy for international confidence decreased. The hungarian government bonds and interest rates in November 2011 increased to $8.5 \%$ This category is higher than the trumpery of Romania

To establish the permanent development it is necessary to employ more: the efficient reform of systems of budget, public administration, education, public health and social welfare.
\end{abstract}

\section{BEVEZETÉS}

A 2011 tavaszi országgyủlési választásokon a FIDESZ-KDNP koalíció rendkívül nagy győzelmet aratott, a kétharmados - alkotmányos - többségnél is több mandátumot szerzett. A választási kampány során a győztes koalíció tervezett gazdaságpolitikájának konkrétumairól nagyon keveset tudhattunk meg. Az a kevés is inkább az I. Orbán-kormány 1998-2002 közötti tevékenysége alapján rajzolódott ki. Az általános elvek persze ismertek voltak. Például, az, hogy a FIDESZ szakítani akar az előző nyolc év - valójában csak négy év!!! - balliberális megszorító politikájával. Továbbá: elutasítja a vagyonadót; az egészségügyi rendszer magánpénztárakon keresztül való múködtetését; a felsőoktatási tandijat; az alacsony kihasználtságú vasúti szárnyvonalak és kisposták bezárását. Kiemelten kívánja támogatni a hazai mikro, kis, valamint középvállalkozásokat, stb.

\section{A II. ORBÁN-KORMÁNY GAZDASÁGPOLITIKÁJÁNAK HÁROM SZAKASZA 2010-2011-BEN}

Véleményem szerint a II. Orbán-kormány 2010 májusa és 2011 októbere között folytatott gazdaságpolitikája három fö szakaszra osztható.

Az első szakasz (2010 nyara) céljai és eszközei röviden talán így fogalmazhatók meg:

a) A világválság elmúltával a folyó évi államháztartási hiány 2-3 százalékpontos növelésével 4-6\%-ra pörgetjük föl a gazdasági növekedés"Kinöjük az adósságot", azaz magas növekedési ütemmel csökkentjük a $80 \%$ körüli GDP-arányos államháztartási hiányt. Az Európai Unió ezt a tervet elutasitotta, és ragaszkodott a Gyurcsány, valamint a Bajnaikormányokkal kötött megállapodásokhoz. Paradoxon, hogy ekkor „küldték el” az IMF-et (portfolio.hu 2010) - pontosabban nem kötöttek vele semmilyen készenléti hitelmegállapodást - pedig az IMF az EU-val ellentétben nem ragaszkodott mereven a 2009 elején - még a Gyurcsány-kormánnyal - kötött megállapodás számaihoz. Az IMF elfogadhatónak tartott volna egy 1-1,5 százalékponttal nagyobb hiányt is, ha ez például zömében a vállalkozások versenyképességének növelésére irảnyuló ảllami többletkiadások miatt következik be.

b) A tavaszi győzelem után a 2010-es öszi önkormányzati választások előtt pedig csak a társadalom számára kedvezö intézkedések születhettek.

Az új gazdasági rendszer 2010 június elején meghirdetett kormányzati akcióterve az elsö ütemben 29 pontot tartalmazott. Például:

- 500 milliós nyereségig 10\%-ra csökkentik a társasági nyereségadó kulcsát 
- 10 kisadót megszüntetnek;

- eltörölik a családon belüli vagyonmozgásokat sújtó adókat és illetékeket;

- bevezetik az adórendszeren kívüli kereset fogalmát, és lehetövé teszik, hogy aki adózott jövedelemböl másnak munkalehetőséget biztosít, annak ne kelljen már adót fizetni." Itt az államnak már nincs keresnivalója"-mondta Orbán Viktor;

-A beruházások során ma 51 engedélyt kell kérni, ennek harmadát a kormány eltörli.

- Ingatlan bérbeadás esetén a bérbeadónak nem kell vállalkozóvá vállalni.

- Adjuk vissza az embereknek a szabad gyümölcspárlat készítésének jogát!

- az adományozás áfa mentessé tétele.

- A kistermelök élelmiszer-termelési, feldolgozási és értékesítési feltételeit könnyítsük;

- A Széchenyi-kártya programot 50 millió forintra bővitsék, és pályázati önerő részére is lehessen használni.

- az EU-s források radikális átrendezése a kkv-k javára.

- Fizessenek a pénzintézetek, azaz banki különadót felemeljük 13-ról 200milliárdra.

- A személyi jövedelemadó kulcsa 16 százalék lesz. A gyermekek számától függően meghatározott nagyságú jövedelem nem eshet adózás alá.

- Az állam 120 milliárd forintot takarít meg saját magán.

- A költségvetési szférában havi bruttó kétmilliós fizetési plafont vezet be a kormány.

- Az állami vagyonkezelés területén elrendelik a bértömeg 15 százalékos csökkentését, amivel 48,2 milliárd forint takarítható meg. Az igazgatóságok számát százról tízre csökkentik. 319 röl 60 före csökkentik az igazgatósági helyeket. A felügyelö-bizottságoknál a törvényi elöírások minimuma, 630-ból 450 marad.

- Teljes telefon-, bútor-, gépkocsi vásárlási és csere stopot rendelnek el a közszférában.

- A két hónapon túli végkielégítések és egyéb, béren felüli juttatások - mint szabadságmegváltás, titoktartási pénz - a költségvetési szférában adózzanak 98 százalékkal.

- Bevezetik a másodlagos élelmiszer-vizsgálatot, hogy ne áramolhasson akadálytalanul. Európa élelmiszer-hulladéka Magyarországra - fogalmazott Orbán Viktor.

- A kormányfö felkéri a Fellegi Tamás vezette minisztériumot, hogy a közüzemi díjak emelésére rendeljen el moratóriumot és kezdjen tárgyalásokat az új árak megállapitására

- Elrendelik a kilakoltatási moratóriumot 2010. december 31-ig és tárgyalásokat kezdeményeznek a bajba jutottak lakáshitelének rendezésére (hvg.hu 2010)

A második szakasz (2010 öszétöl):"a fö ellenség az adósság”, ezért a kormány teljesíti a 2010-re vállalt 3,8\%-os, a 2012 és 2013-ra vállalt 3\% alatti GDP-arányos államháztartási hiánycélt.( MTI 2010) A teljesítés céljából a már 2010 júliusában bevezetett banki különadó kb. évi 180-200 milliárd forint (Független Hírügynökség 2010) - mellé válságadókat - kb. évi 160 milliárd forint az energia és távközlési szektorra, valamint a nagykereskedelmi láncokra (Kormánykrónikás 2010)- vezetett be. Államosította a kötelezö tagságú magánnyugdíjpénztárakba befizetett évi 360-400 milliárd forintot, valamint a pénztárak 14 év alatt felhalmozott 2650 milliárdos vagyonát. A vagyon felét 2011-ben folyó költségvetési kiadásokra, valamint az egykulcsos személyi jövedelemadó bevezetése miatt kieső kb.: 500 milliárd forint és egyéb adócsökkentések és kedvezménynövekedések(pl. társasági adó csökkentése, gyermekek után járó adókedvezmény növelése ) miatt kieső - összesített egyenlegét tekintve a GDP 4-5 \%-a (Oszkó 2011), azaz 1100-1400 milliárd forint körüli összeg - pótlására, másik felét pedig adósságcsökkentésre fordította és fordítja. Ennek következtében a 82\%-os felhalmozott GDP-arányos államháztartási hiány azonnal csökkent 5 százalékponttal. Egyúttal a hosszú távú adósságunk - az úgynevezett strukturális adósság pedig a teljes nyugdíjpénztári vagyon és a folyó befizetések értékével - azaz ugyanennyivel növekedett (ecoline.hu 2011).

A kormány természetesen tudta, hogy 2012-ben már nem áll rendelkezésre a nyugdijpénztári vagyon, ezért 2011 tavaszára elkészítette az állami nagyrendszerek 
strukturális átalakítását is célul kitüző Széll Kálmán Tervet, majd döntỏen erre alapozva az EU által évente kötelezően elöirt konvergencia programot is. „Hatalmas, ezermilliárdos és annál is nagyobb lyuk tátongana a következö években a költségvetésben, ha a kormány nem hajtaná végre a Széll Kálmán Tervbe foglalt megszoritásokat, és azokat nem fejelné meg a konvergencia programba rejtett - további kiigazító lépésekkel - így foglalható össze annak az elemzésnek az üzenete, amelyet a tavaly év végén szélnek eresztett Költségvetési Tanács elemzői stábjảnak néhány tagja készitett"(Baksa 2011). A további kiigazitó lépések 2012-re: a személyi jövedelemadó adójóváírásának csökkentése, a jövedéki adók emelése, stb..

A harmadik szakasz ( 2011 öszétöl ) időben részint összefonódik a második szakasszal. Lényege talán így foglalható össze: a bankokat törvényi szabályozással kötelezték, hogy az adósok számára tegyék lehetővé a lakossági devizahitelek rögzített árfolyamon való egyösszegü végtörlesztését. Ez a bankoknak - a végtörlesztés lehetöségével élők arányától függően - 300-1000 milliárd forintra becsült veszteséget okozhat. Ennek következtében számolni kell a hazai és nemzetközi hitelpiac radikális beszükülésével, a kamatlábak jelentős emelkedésével az ország nemzetközi leminősítésével, a gazdasági növekedés ütemének és a beruházások csökkenésével.

A hazai beruházások már - a végtörlesztési törvény elfogadása előtt - 2011 második negyedévében is 6,5\%-kal voltak kisebbek az előző év azonos időszakához képest (KSH 2011). Egyetlen, - de rendkívül fontos pozitivum - hogy exportunk 2011-ben is rendkívül dinamikusan nött, és a külkereskedelmi mérlegünk aktívuma várhatóan eléri a 7 milliárd eurót (mfor.hu 2011).

\section{3. ÖSSZEFOGLALÁS/KÖVETKEZTETÉSEK/EREDMÉNYEK}

A FIDESZ 2010. évi országgyülési választási stratégiáját arra építette, hogy a kampány során nem árult el semmilyen lényeges - különösen megszorításként értelmezhetö elemet tervezett gazdaságpolitikájából. A tavaszi gyözelem után a 2010-es őszi önkormányzati választások elött pedig csak a társadalom számára kedvező intézkedések születtek. A 2. fejezetben ismertetett 29 pontos program szinte mindenki - föként a kisemberek és a kkv-szektor - számára nemcsak ígért valamit, hanem 2010 őszére már részint teljesitette is. Olyan széles körben elterjedt és népszerü nézeteket tükröző szólásokra tartalmaz rejtett utalásokat, mint a „Elmentek a tankok, megjöttek a bankok." Fizessenek a gazdagok"- miközben bevezeti az egykulcsos adót. A "termelö munka becsülete" a spekulációra épülő pénzügyi tevékenység helyett. Ha lehet, a saját, helyben megtermelt termékeinket fogyasszuk."Három gyermek, három szoba, négy kerék"- Orbán Viktor szállóigévé vált mondatai, amelyekhez 2000-ben az adókedvezményekkel megerősített kedvezményes kamatozású lakáskölcsönök társultak, - segítve a középosztály családalapításra készülö tagjainak alapvető törekvéseit, stb.

2002 és 2010 között Orbán Viktor és csapata csak a választási győzelemre készült, de nem készült fel a kormányzásra. Gazdasági szakértöik pontosan tisztában voltak az ország helyzetével. Egyértelmünek tünhetett számukra, hogy az EU a Medgyessy és a Gyurcsány kormányoknak 2002 és 2006 ösze között folytatott - az ország külső és belső gazdasági egyensúlyát felborító - felelőtlen politikảja után nem engedélyez egy alapvetően a belső kereslet élénkitésére és a költségvetési hiány növelésére alapozott gazdaságfejlesztési stratégiát. $\mathrm{Az}$ „első szakasz” az önkormányzati választásokon aratott fölényes FIDESZ győzelem révén inkább csak belpolitikai sikert hozott.

A „második szakasz" egyértelmüen megmutatta, hogy a II. Orbán-kormány a különadókból és a magán-nyugdíjpénztári befizetések államosításából származó több mint 700 milliárd forint többletbevételre és a 2650 milliárd államosított magán-nyugdíjpénztári vagyonra az 1-2\%-os gazdasági növekedés forrásaira támaszkodva is csak nehezen tesz eleget a Konvergencia Program követelményeinek. Az elöbbiekben felsorolt rendkívüli források 
felhasználásával 2010-ben és 2011-ben a költségvetési hiánycélok számai viszonylag könnyen teljesíthetök voltak és lesznek. 2012-re viszont kb. 1400 milliárd forint államháztartási egyenlegjavulást kellene elérni a 2,5\%-os GDP-arányos államháztartási hiány teljesítéséhez. Ezt a 2012-es állami költségvetési tervet - a 300 forintos euró-árfolyam, a 10\%-hoz közeledő kamatlábú állampapírok, a különadók, valamint a bankokat 300-1000 milliárd forint veszteséggel fenyegetö végtörlesztési törvény, stb. miatt - sem a hazai, sem a külföldi szakértők és befektetök nem látják megvalósíthatónak; bár a kormány $27 \%$-ra kívánja emelni az ÁFA- kulcsot, sőt ủjabb adók bevezetésére készül. Hazánkat jelenleg a kormány ellentmondásos gazdaságpolitikája miatt az általános leminösítés veszélye fenyegeti. $\mathrm{Az}$ adósságkockázati rangsorban a „még befektetésre ajánlott” kategóriából a „befektetésre nem ajánlott, azaz a „bóvli” kategóriába kerültünk 2011. november 25-én, amikor az egyik nagy hitelminösítö - a Moody's - a magyar kormánykötvényeket egy fokozattal lejjebb sorolta. A tízéves lejáratú magyar államkötvények hozamrátája 2011 novemberében már magasabb volt, mint a román papíroké, pedig Románia - igaz, hogy 40\%-os GDP-arányos államháztartási hiánnyal - a „bóvli” kategóriában van, de ott áll mögötte az IMF (index.hu 2011). Ha helyzetünk tovább romlik, akkor elkerülhetetlenné válik a hazai jegybanki alapkamat jelentős emelése, ami növelné az üzleti kamatlábakat is, csökkentve a beruházási kedvet, és növelné a hazai költségszínvonalat, csökkentve a hazai üzleti szféra versenyképességét. $\mathrm{Az}$ állampapírok $10 \%$ körüli hozamrátája már középtávon is nehezen kifizethető terhet jelent hazánk számára, ezért elkerülhetetlen az IMF-fel és az EU-val való hitel-megállapodás megkötése és az állami közszolgáltató rendszerek hatékony strukturális

\section{IRODALOMJEGYZÉK}

Baksa R. (2011): A két csomag nélkül hatalmas lyuk tátongana a költségvetésben http://www.origo.hu/uzletinegyed/hirek/20110420-a-szell-kalman-terv-es-akonvergenciaprogram-nelkul-h

Oszkó P. (2011): Lehetséges konvergencia pályák

http://hazaeshaladas.blog.hu/2011/05/27/lehetseges_konvergenciapalyak

MTI ( 2010): Londonban normalizálódni látják a magyar gazdaságpolitikát.

http://hvg.hu/gazdasag/20100923 londoni elemzok magyar gazdasagpolitika n

Független Hírügynökség (2010): Döntött a banki különadóról a parlament

http://www.mon.hu/hirek/frisshirek/cikk/d246nt246tt-a-banki-k2521246nadorol-a-

parlament/cn/haon-news-charlotteInform-20100722-1002095920

hvg.hu (2010): Íme, Orbán 29 pontja

http://hvg.hu/gazdaság/20100608_Orban_gazdasagi_akcioter

index.hu (2011): Elfogyott a kormány hitele

http://index.hu/gazdasag/magyar/2011/11/17/elfogyott a kormany hitele/

ecoline.hu (2011): Alulmaradhat a kormány az államadósság elleni harcban

http://ecoline.hu/makro/2011/9/28/Alulmaradhat a kormany az allamadossag elleni harc

Kormánykrónikás (2010): Válságadók

http://kormanykronika.blog.hu/2010/10/25/valsagadok_1\#more239722

KSH (2011): Kétszer akkorát csökkentek a nemzetgazdasági beruházások, mint várták http://atv.hu/penztarca/20110831 ketszer_akkorat_csokkentek a nemzetgazdasagi beruhaza sok mint vartak 